\title{
POLSKIE DOŚWIADCZENIE HISTORYCZNE A SŁOWIAŃSKA PERSPEKTYWA LITERACKA EUROPY ŚRODKOWO-WSCHODNIEJ (CZESŁAW MIŁOSZ, MILAN KUNDERA, DANILO KIŠ) ${ }^{1}$
}

\author{
MARgreta Grigorova
}

\author{
St. Cyril and St. Methodius University of Veliko Tarnovo
}

\begin{abstract}
THE POLISH HISTORICAL EXPERIENCE AND THE SLAVIC LITERARY PERSPECTIVE TO CENTRAL AND EASTERN EUROPE (CZESLAW MILOSZ, MILAN KUNDERA, DANILO KIS). The text presents the literary reflections of Cz. Milosz, M. Kundera and D. Kis on Central and East-Central Europe in the light of comparative Slavic analysis. Their views are positioned as phases and aspects in the development of the concept of the region in question. The main focus falls on the dialogue between key texts and concepts of the above-mentioned writers on the subject, including their biographies, émigré and dissident contexts, their historical and cultural awareness. At the center of the comparative interpretation are Czesław Miłosz's views in relation to Polish historical experience regarding the heritage of the Polish-Lithuanian Commonwealth.

Key words: Central and Eastern Europe, Czeslaw Milosz, Milan Kundera, Danilo Kis
\end{abstract}

\section{POWRACAJĄCY TEMAT}

Temat Europy Środkowej / Środkowo-Wschodniej² może wyglądać na banalny i wyczerpany po kilku dekadach popularności w polskim i międzynarodowym kontekście, nasyconym obfitymi tradycjami i zakreślony wyraźną polską wizją³. Nie ulega jednak wątpliwości,

1 Tekst wygłoszono na III Kongresie Zagranicznych Badaczy Dziejów Polski / 3rd Congress of International Researchers of Polish History, 11-14.10.2017 w Krakowie. Na potrzeby niniejszej ninieszej publikacji został przerobiony i zaktualizowany.

2 Przyjmujemy uwagi, dotyczące aspektów synonimiczności dwóch pojęć, wyjaśnionych przez Martę Cobel -Tokarską. Bliższy celom niniejszej interpretacji jest koncept Europa Środkowo-Wschodnia ze względu na wschodnią orientację przede wszystkim poglądów Miłosza, korespondujący z wskazaną przez M. Cobel-Tokarską charakterystyką: Określenie to z jednej strony odcina się od niemieckiej Mitteleuropy, z drugiej silnie wskazuje na Wschód. Podkreśla dziedzictwo I Rzeczpospolitej, idealizując mit wielokulturowych Kresów. (zob. Cobel-Tokarska 2013: 172-192).W ramach niniejszego tekstu nie będę odnosić się do dyskusji nad różnymi nazwami i pojęciami.

3 Decydującą rolę w tym kierunku odegrały prace Oskara Haleckiego (1891-1973), uważanego za inicjatora wprowadzenia pojęcia Europy Środkowo-Wschodniej do nauki historycznej (Kloczowski 2013: 883) i Jerzego Kłoczowskiego (ur. 1924, twórcy Lubelskiego Instytutu Europy Środkowo-Wschodniej - por. Halecki 1943; Halecki 1950; Halecki 1952; Halecki 1994; Kloczowski 1993; Kloczowski 1998). 
że w wyniku dyskusji i badań nie tylko ostatnich dekad, ale i ostatnich dwóch wieków, Europa Środkowo-Wschodnia umocniła się jako jądro Europy, jako topos, wyrażający istotę najważniejszych procesów europejskich. Nie można też zaprzeczyć, że topos ten jest ściśle związany z historią Polski oraz z geopolityczną i geokulturową pozycją krajów, z których pochodzą, będący przedmiotem moich rozważań, pisarze: Czesław Miłosz (1911-2004), Milan Kundera (ur. 1929) i Danilo Kiš (1935-1989).

W ostatnich latach temat Europy Środkowej / Środkowo-Wschodniej nabiera nowego znaczenia. Tak zwane widmo Europy Środkowej ${ }^{1}$, rejestruje nowe formy obecności i stawia nowe pytania. Stosunkowo niedawno (25.04.2017) w Warszawie wygłosił odczyt o kryzysie Europy p.t. Is Europe disintegrating? (Czy Europa się rozpada?) znany brytyjski historyk i europeista Timothy Ash (Ash 2017). W 1986 r. uczony zadał prowokacyjne pytanie o istnienie Europy Środkowej w znanym tekście Does Central Europe Exist, który ukazał się w języku polskim 4 lata później (Ash 1990: 168-175). W warszawskim odczycie z 2017 roku Ash obronił uniwersalną tezę, że kryzys rozpoczyna się w latach triumfu, a współczesny kryzys Europy rozpoczął się w 1989 roku - czyli w czasie, w którym zaczęto rozwiązywać problemy stawiane przez Kunderę, Miłosza i Kiša.

W Bułgarii zainteresowanie Europą Środkową też nie zmniejszyło się, chociaż temat ten nie ma tam tak fundamentalnego znaczenia jak w Polsce. Warto zauważyć, że w Bułgarii dominuje orientacja bałkańska i południowo-wschodnia, a stosunek do europejskiego Wschodu ma inne niż w Polsce polityczne i kulturowe przesłanki i tradycje. W pierwszej dekadzie nowego tysiąclecia w międzynarodowej dyskusji o relacjach na linii Bałkany - reszta Europy zyskały popularność znane w Polsce prace Marii Todorovej o wyobrażonych Bałkanach (Todorova 2009). Zasługuje na uwagę wydany w 2005 roku specjalny, obszerny numer czasopisma Język i literatura², poświęcony tematowi Europa Środkowa i kultura bułgarska, gdzie brakuje polskiego tekstu i odniesienia do poglądów Miłosza (może być kojarzony z problematyką Europy Wschodniej). Warto w tym miejscu zauważyć, że polski

1 Większość interpretacji z ostatnich dekad XX wieku kładzie nacisk właśnie na nieuchwytność, relatywność, płynność pojęcia oraz jego przestrzennego ekwiwalentu. Zdaniem Danilo Kiša Europa Środkowa przypomina dziś coraz bardziej owego smoka z Alca z Wyspy pingwinów Anatola Franc'a, z którym porównywano nurt symboliczy: nikt z tych, którzy twierdzili, że go widzieli, nie umiał powiedzieć, jak wygląda (Kis 1989: 21). Definicja tropologiczna Kiša brzmi jako zapowiedź widmologii, zainicjowanej przez ojca dekonstrukcji Jacques Derrida w Widmach Marksa (1993). Jeżeli spojrzymy w ten sposób na widmowość Europy Środkowej możemy oczekiwać na dalsze nawiedzenia widma, na nowe powroty jej istoty.

2 Autorami tekstów numeru są m.in.: Milan Kundera, Danilo Kiš, Josef Kroutvor, Pavel Vilkowski, Mihajlo Pantić, Zoran Konstantinović i Friedrun Rinner, Jacques le Rider, Gottfried Heindl, Alfred Pfabigan, Jürgen Fröhlich. Warto zwrócić uwagę na świetne artykuły bułgarskich autorów - bohemistów Ani Burovej (o czeskich tekstach w kontekście slawistycznym - Burova 2005: 99-104) i Dobromira Grigorova (o czeskiej debacie - Grigorov 2005: 75-84). 
noblista ma wyjątkowo silny odbiór w Bułgarii, który osiągnął swój szczyt w latach 2011-2013 z okazji stulecia urodzin pisarza (2011 rok) ${ }^{1}$ W recepcji przekładowej Miłosza ze względu na tematykę Europy Wschodniej i Środkowo-Wschodniej w Bułgarii ważne miejsce zajmują jego: Rodzinna Europa ${ }^{2}$, przemówienie noblowskie i wygłoszony z tej okazji wykład ${ }^{3}$ oraz wykłady harwardzkie (z lat 1981/82)4. Do tej pory tekst programowy O naszej Europie nie został przetłumaczony i opublikowany na język bułgarski.

Aktualność dyskusji o Europie Środkowej nie zamyka się z końcem XX wieku. Niniejszy tekst jest motywowany także ważnością tego tematu w pierwszych dziesięcioleciach XXI wieku. O najnowszych współczesnych kontynuacjach idei, o idealizacji, utopijnej wizualizacji i geograficznej płynności i względności Europy Środkowej pisze też bułgarska slawistka Ani Burova, szukając argumentacji w twórczości i poglądach czeskiego pisarza Jáchyma Topola, polskiego prozaika Andrzeja Stasiuka, ukraińskiego poety i prozaika Jurija Andruchowycza, czy w końcu eseisty słoweńskiego - Drago Jančara. Wychodząc od podstawowych tekstów Milana Kundery, Danilo Kiša i Czesława Miłosza z lat 8o. XX stulecia, autorka stara się ukazać ciągłość między ich ideami a wizjami wymienionych twórców z pierwszej dekady XXI wieku:

Idealizacja Europy Środkowej w najwyższym stopniu pojawia się w II połowie XX wieku, szczególnie w latach 8o. minionego stulecia, gdy Milan Kundera, Danilo Kiš i inni autorzy ze środowisk emigrancko-dysydenckich formułują o niej utopijną wizję; w ich wyobrażeniu przestrzeń środkowoeuropejska to alternatywa dla ideologicznego banału, sprowadzającego się do rodzimych literatur i kultur (...) Okazuje się jednak, że również po ustąpieniu ideologicznej polaryzacji, wizja Europy Środkowej początku XXI wieku jest ważnym fundamentem tożsamości dla dużej części wschodnioeuropejskich kultur, a jej obraz wciąż jest żywy w twórczości literackiej. (Burova 2015: 75)

W niniejszym opracowaniu pragnę zwrócić uwagę na znaczenie i rolę historycznej samoświadomości noblisty, dotyczącej Dawnej Rzeczypospolitej i jej wschodnich, litewskich regionów, rodzinnych stron pisarza, opisanych w szeregu publikacji. Zaliczyć do nich należy

1 Zob. artykuły, reprezentujące recepcje Miłosza, opublikowane w bułgarskim numerze czasopisma Postscriptum Polonistyczne, 2013, nr 2 (Bachneva 2013: 166-176; Grigorowa 2013: 177-190).

2 Wyd. w 2012 r. w przekładzie Miry Kostowej i Margrety Grigorowej, prezentująca pragnienie noblisty przybliżyć Europę Europejczykom, rehabilitując wschodniego Europejczyka, z akcentem na ojczyste (wschodnie) terytoria.

3 Wyd. w 2001 r. w przekładzie z angielskiego, w 2011 r. w przekładzie z polskiego przez Manola Glisheva i Bogdana Glisheva.

4 Wyd. w 2017 r. w przekładzie Bogdana Glisheva, przedstawione w maju 2020 przez Marina Bodakova w zorganizowanej przez Instytut Polski w Sofii serii on line (na kanale You Tube) O najcichszych przyjaciołach i najmądrzejszych doradcach: ksiq̨żkach (За най-тихите приятели и най-мъдрите съветници - книгите). 
oprócz wymienionych dzieł Miłosza także Dialog o Wilnie (opublikowany w emigranckiej Kulturze w r. 1979), przemówienie wileńskie z 1999 roku pt. Aby duchy umarłych zostawity nas w spokoju (wygłoszone na zorganizowanym przez Instytut im. Goethego i Instytut Polski spotkaniu, gdzie wystąpili jeszcze Günter Grass, Wisława Szymborska i Tomas Venclova; później dołączono go do trzeciego wydania tomu Szukanie ojczyzny, 2001). Warto zauważyć, że Rodzinna Europa (wyd. po raz pierwszy w 1959 roku na emigracji) poprzedza teksty noblisty z lat 8o. XX w., uważane za kluczowe w dyskusji o Europie Środkowo-Wschodniej. Należy także zwrócić uwagę na orientację czasową tych tekstów wobec Nagrody Nobla, która oczywiście wzmocniła pozycję Miłosza i podnosiła status jego wypowiedzi.

Teksty Miłosza stawiam w kontekście porównawczym z tekstami programowymi Kundery i Kiša według klucza historyczno-kulturowego ich ojczystych krajów oraz podklucza kategoryzacyjnego ich emigranckich i pogranicznych biografii, przyjętych jako wiodące kryteria badania. Ważna w tym aspekcie jest korespondencja między tekstami oraz sytuacja dysydencka i międzynarodowa. Interpretacja Europy Środkowej / Środkowo-Wschodniej jest tu ściśle związana z powyższymi dwoma kryteriami. Analizowane teksty są w badaniu obiektami 1) międzykulturowego i międzykontynentalnego komunikowania oraz 2) elementami pewnej fazy rozwoju pojęcia ${ }^{1}$, idei i mityzacji Europy Środka z perspektywy pisarza.

Jest to faza, czasowo i ideowo usytuowana w okresie po II wojnie światowej do lat 90. - okres przełomowy dla krajów słowiańskich, które, osiągając niezależność polityczną po I wojnie światowej, znów ją tracą. Oczywisty jest ogólnoeuropejski sens górnej i dolnej granicy czasowej wymienionego okresu. Wojna jako przyczyna totalnej dyskredytacji niemieckiego konceptu Mitteleuropa (powstałego w kluczowej książce Friedricha Naumanna pod tym samym tytułem, nazwanej prez A. Podrazę ewangelią koncepcji „Europy Środkowej”

1 Prawie każda praca, która porusza problematykę środkowoeuropejską, zawiera przegląd stanowisk badawczych tworzących bardziej czy mniej złożony obraz jej ewolucji w określonych granicach czasowych. Wśród licznych prac, dotyczących historii pojęcia i idei, można wymienić: Jacques Droz - L'Europe Centrale. Evolution historique de l'idee de Mitteleuropa (Paryż 1960) oraz L'Europe Centrale. Evolution historique de l'idee de "Mitteleuropa" (Revue française de science politique, no 1, vol. 12 (1962), pp. 216-218); Henry Cord Meyer - Mitteleuropa in German Thought and Action, 1815-1945 (Nijhoff 1955); Jacques le Rider - Mitteleuropa: Próba krótkiej historii pojęcia (Wiedeń 1994). Krótkie i treściowe przedstawienie ewolucji pojęcia odnajdujemy w tekstach polskich badaczy: Antoni Podraza (Podraza 2004) oraz w wyżej cytowanym artykule M.Cobel-Tokarskiej Europa Środkowa - dawne i nowe znaczenia. Przyjmuję ujęcie ewolucji tego pojęcia, przedstawione przez Cobel-Tokarską: Główne okresy w rozwoju idei środkowoeuropejskiej to czas do 1918 roku, lata 1918-1945; następnie jej renesans w latach 70.-80. XX wieku, oraz okres po 1989 roku (Cobel-Tokarska 2013: 176). 
jako obszaru niemieckiej hegemonii ${ }^{1}$ ), jako szok egzystencjalny i cywilizacyjny, który rzucił cień nie tylko na nazwę, lecz także i na pojęcie i doprowadził do jego zasadniczej metamorfozy i nowej formy. Wyraźnie mówi o tym T. G. Ash:

I znów mamy Europę Środkową. Poczynając od roku 1945 przez trzy dziesięciolecia nikt nie mówił o niej w czasie teraźniejszym. Dzieliła los Niniwy i Tyru. W krajach języka niemieckiego termin Mitteleuropa zginął, jak się zdawało, razem z Hitlerem. (...) W ciągu ostatnich kilku lat zaczęliśmy jednak na nowo mówić o Europie Środkowej i to mówić w czasie teraźniejszym. Nowa debata została zapoczątkowana nie w Berlinie czy Wiedniu, lecz w Pradze i Budapeszcie. (Ash 1990: 168)

O znaczeniu górnej granicy dla nowej interpretacji Europy Środkowej pisze wyraźnie Agata Stolarz w artykule Nieznośny ciężar historii? Dyskurs środkowoeuropejski od lat osiemdziesiątych do współczesności:

Wydarzenia roku 1989 w oczywisty sposób wpłynęły na koncept Europy Środkowej. Nie było już potrzeby odcinania się od Wschodu. W latach 9o. posługiwano się nim przede wszystkim po to, by wyrazić podobieństwo Czech, Polski, Słowacji i Węgier do krajów Europy Zachodniej. (Stolarz 2013: 30)

Kreśląc perspektywę dalszego rozwoju pojęcia, autorka określa Grupę Wyszehradzką (powstałą z inicjatywy Vaclava Havla) jako przemianowanie intelektualnego konceptu Europy Środkowej, opartego na wspólnej tożsamości kulturowej, w polityczne działanie, które dziś coraz bardziej wskazuje cechy reliktu pamięci (Stolarz 2013: 24).

Niniejszy artykuł skupia się przede wszystkim na wyżej wymienionym okresie, nie opuszczając z pola widzenia relacji, dotyczących innych faz i czasów. Podane w tytule określenie słowiańska kojarzy się zarówno z typem państwa, z którego pochodzą pisarze, z ich sytuacją geokulturową i geopolityczną w określonej perspektywie czasowej, jak i z krytyczną analizą słowiańskości, prowadzoną głownie przez Kunderę. W programowym tekście Zachód porwany albo tragedia Europy Środkowej (1983) autor dokonuje destrukcji mitu słowiańskości (Bobrownicka 1995: 91-101), krytykuje pojęcie słowiańskiej duszy i inicjuje nową recepcję czeskich i słowiańskich idei Odrodzenia², reinterpretując

1 Jak zauważa A. Podraza, klęska Niemiec w pierwszej wojnie i rozpad Austro-Węgier przeszkodziły jednak w realizacji tych planów. Koncepcja odżyła znów dopiero w czasach Adolfa Hitlera w zmienionej już formie (Podraza 2004: 2).

2 Na wskazane aspekty zwracają uwagę polska badaczka Karolina Pospiszil i bułgarski bohemista Dobromir Grigorov (Pospiszil 2011: 141-153; Grigorov 2005: 75-83). 
na przykład poglądy austriacko-slawistyczne Franciszka Palackiego ${ }^{1}$. W swojej krytyce słowiańskości Kundera odsyła do książki Josepha Conrada A Personal Record (1912), gdzie autor wyraźnie izoluje się od naiwnego slawizmu². Podobną krytykę możemy spotkać u Kiša, który podnosi, że serbski nacjonalizm ma związki z panslawizmem. O rosyjskiej duszy słowiańskiej (âme slave) Miłosz pisze jak o jednym z dwóch stereotypów, w którym najmniej można pomieścić wschodniego Europejczyka. Drugim stereotypem jest niemiecki porządek (Deutsches Ordnung)3. W tym jego określeniu można zauważyć typowy dla Europy Środkowo-Wschodniej problem dwóch destrukcyjnych nacisków na Europejczyka Europy Środka - niemieckim i rosyjskim4 Ich działania Miłosz szczegółowo przedstawia w wymienionych tekstach.

W prowadzonym dialogu pisarskim Miłosz przedstawia skomplikowany los wschodnich granic dawnej Polski jako aspekt problematyki Europy Środkowo-Wschodniej. Zauważa ten aspekt Antoni Podraza, pisząc, że wschodnie granice Europy są granicami dawnej Polski (Podraza 2004). Właśnie tzw. Kresy Polskie stymulują pamięć o Dawnej Rzeczypospolitej, ponieważ określają jej stare przestrzenne i czasowe granice, kiedy to Polska i Litwa tworzyły choć niełatwo jeden organizm państwowy, dramatycznie rozerwany przez politykę. Łącząca przez prawie 200 lat dynastia Jagiellonów (chociaż na początku Litwa zachowała przez długi czas swoją odrębność) i scalająca oba narody Unia Lubelska formują, jak czytamy w akcie Unii, jedno nieróżne i nierozdzielne ciało, także nieróżną, ale jedną wspólną Rzeczpospolitą. W taki sposób Unia lubelska stworzyła wielonarodowa Rzeczpospolitą, złożona z dwóch równoprawnych podmiotów - Polski i Wielkiego księstwa Litewskiego, a trwałość

1 Frantisek Palacky, znakomity historyk i najwybitniejsza postać czeskiej dziewiętnastowiecznej polityki, $w 1848$ roku napisat stynny list do frankfurckiego parlamentu rewolucyjnego, $w$ którym bronit $i$ usprawiedliwiat cesarstwo Habsburgów, jedynq ochronę przed Rosją, „mocarstwem, które osiągnquwszy dziś ogromna potęgę, pomnaża swą siłę bardziej niżby mógł to uczynić jakikolwiek kraj zachodni”. Palacky ostrzega przed imperialnymi ambicjami Rosji, która usiłuje stać się „monarchiq światową”, tj. zmierza do panowania nad światem (Kundera 1984).

2 Blisko sześćdziesiąt lat temu Józef Konrad Korzeniowski, znany pod nazwiskiem Joseph Conrad, zirytowany etykietka „duszy słowiańskiej”, jaką chętnie mu przyczepiano z racji polskiego pochodzenia, pisat, iż nie ma nic bardziej obcego temperamentowi polskiemu z jego rycerskim poczuciem obowiązku moralnego i przesadnym poszanowaniem praw jednostki niż to, co w świecie literackim nazywa się „duchem słowiańskim”. Jakże go rozumiem! Ja tė̇ nie znam nic żałośniejszego niż ten kult mrocznych głębi, ten sentymentalizm tyleż głośny, co pusty, który nazywaja „duszq słowiańskq” i przypisujq mi czasami! A jednak idea słowiańskiego świata stała się komunatem w historiografii (Kundera 1984).

3 Postanowiłem więc napisać książkę o Europejczyku wschodnim (...), o człowieku, który mniej niż ktokolwiek mieści się w stereotypowych pojęciach niemieckiego porządku i rosyjskiego „âme slave” (Milosz 2001: 13). 4 Zbieżna z wyżej cytowaną wypowiedzią Miłosza jest myśl Karela Kosíka, który w jednym ze swoich esejów pisat, że Środkowoeuropejczycy - w odróżnieniu od Niemców czy Rosjan - nie moga mówić o czymś na ksztatt „niemieckiego ducha”czy „rosyjskiej duszy”, raczej o jakiejś niepewności i nieokreśloności (Pospiszil 2011: 142). 
tego zwiq̨zku potwierdziły dwa następne stulecia wspólnych dziejów (Dybkowska \& Zaryn \& Zaryn 2002: 94). Ich scalenie, wspólna przeszłość i podział odbijają się i w losie i w świadomości Miłosza i w największym stopniu określają jego wizję Europy.

\section{DLACZEGO DECYDUJĄ PISARZE?}

Poglądy o Europie Środkowo-Wschodniej pisarzy dysydentów Czesława Miłosza, Milana Kundery i Daniło Kiša należy wpisać do klasycznych definicji tego pojęcia w ich kontekście historyczno-kulturowym drugiej połowy XX wieku, a przede wszystkim lat 8o. Związane są one z rozpadem ZSRR i końcem zimnej wojny po II wojnie światowej.

Lata 8o. są powszechnie uważane za szczyt debaty o Europy Środkowej, która według słów Timothy'ego Garton Asha przez cała niemal dekadę lat osiemdziesiątych toczyła się w Europie i Ameryce. Dominuje w owej debacie, zdaniem brytyjskiego historyka, postrzeganie idei raczej niż wojsk, kultur raczej niż gospodarek, narodów raczej niż systemów politycznych, a przede wszystkim konkretnych osób raczej niż bezkształtnych zbiorowości (Ash 1990: 3).

Dyskusja ta jednak ma szerszy wymiar. Polski historyk Jerzy Kłoczowski uważa, że druga połowa XX wieku to czas, w którym cała dyskusja wokół określeń tego typu jak Europa Środkowa, Wschodnia, Środkowo-Wschodnia itd. nabrała szczególnego znaczenia... Nie tylko naukowego, historycznego, ale też politycznego i, szerzej, cywilizacyjnego, ważnego dla przynależności danego kraju i obszaru do określonego kręgu cywilizacyjnego (Kloczowski 2004). Nieprzypadkowo zatem znany polski badacz Europy Środkowo-Wschodniej - tak zwanej Młodszej Europy, stawia akcent na cywilizacyjny aspekt tego pojęcia, wiodący dla koncepcji badanych tu twórców. Nie jest przypadkiem także, że nową fazę dyskusji o Europie Środkowej zapoczątkowują przede wszystkim pisarze-dysydenci, przedstawiciele tzw. małych narodów (Kundera, Kiš) z małych ojczyzn (Miłosz), z pogranicza zmieszanych rodowodów (Miłosz, Kiš), skonfliktowani z panującym reżimem w ich krajach. Państwa, z których pochodzą, znajdują się w omawianym okresie pod polityczną kontrolą Sowieckiego Imperium, przeżywają kulturowy i egzystencjalny dramat. Zasadne jest zatem pytanie dlaczego pisarze dysydenci odgrywają tu tak istotną rolę.

$\mathrm{Na}$ tę charakterystyczną cechę dla badanego dyskursu zwraca uwagę Andrzej Czarnocki, pisząc, że pojęcie, które zrodziło się w okresie międzywojennym, odżyło ponownie nie za sprawa historyków, lecz głównie pisarzy opozycyjnych w stosunku do panujących reżymów opozycyjnych, który go potraktowali w sposób nie ściśle naukowy, lecz obrazowy (Czarnocki 1994: 28). Dla krajów słowiańskich, z których pochodzą Miłosz, Kundera i Kiš, idea Europy Środkowej staje się kwestią obrony ich cywilizacyjnej egzystencji i kulturowej tożsamości, uwarunkowanej przecież ich historyczno-społecznym rozwojem. 
W historycznej tradycji ich krajów tożsamość kulturowa i cywilizacyjna jest synonimem zachowania egzystencji w warunkach dominacji obcych struktur państwowo-politycznych. Tradycyjnie taką formę zachowania tożsamości ich rodzime tradycje łączyły z głosem literatury na emigracji i jej twórcami. W omawianym okresie sytuacja ta ponownie odżyła. Emigracja twórcza (stan wygnania) była i pozostała alternatywną formą zachowania i budowania własnej pisarskiej tożsamości. Widać to w ich biograficznej i egzystencjalnej pozycji, w jakiej kształtowały się ich idee, twórcze koncepcje i literackie pomysły.

Koncepcja Europy Środkowej może być tu zatem rozumiana jako próba wyzwolenia i obrony własnej tożsamości, a jej interpretacja, jako lustro odbijające specyfikę Europy Środkowej. Istota ta nie ma ponadnarodowego, czy też nacjonalistycznego charakteru, wręcz przeciwnie - jest kosmopolityczna, przeciwstawia się nacjonalizmowi, ale też nie ufa ideom ponadnarodowości. A zatem, patrząc nawet z perspektywy historycznej, trudno jest mówić o środkowoeuropejskiej kulturze jako o ponadnarodowej wspólnocie i całości. Między kulturami w tym regionie istniejq̨ większe różnice niż podobieństwa, żywsze sq̨ antagonizmy niż tendencje do zgodności... (Kis 1989: 21) - pisze Kiš, przypominając tym formułę Kundery o Europie Środkowej jako zminiaturyzowanym modelu Europy narodów opartym na regule: maksimum różnorodności na minimum przestrzeni (Zachód porwany...). U Kiša tendencje nacjonalistycznie widać w panslawizmie, u Miłosza - jako punkt negatywny w ocenie historycznej wspólnoty polsko-litewskiej widziany właśnie jako odradzający się nacjonalizm i po jednej, i po drugiej stronie. Polski noblista Czesław Miłosz powiedział w O naszej Europie, że w pewnym stopniu obca władza i zależność polityczna neutralizowała nacjonalistów: Trzeba jednak przyznać, że moja Europa jest domenq zaciekłych nacjonalizmów, zwróconych przeciwko zewnętrznej kontroli, ale również zwracających się jeden przeciwko drugiemu i, jako taka, może być łatwo odpisana na straty, ponieważ, skoro stanowi potencjalne ognisko zadrażnień, dobrze, że ma przynajmniej jednego strażnika. Gdyby nie rządy Moskwy - brzmi argument - narodowości tego regionu skoczyłyby sobie do gardet (Milosz 1986: 5). O destrukcyjnej roli nacjonalizmu i roli zewnętrznej dualistycznej monarchii austro-węgierskiej pisze niemało Kundera z odblaskiem nostalgii odnośnie roli Austrii:

Cesarstwo austro-węgierskie miało okazję stworzyć silne państwo w Europie Środkowej. Niestety, Austriacy byli rozdarci między aroganckim nacjonalizmem wielkich Niemiec a własną misją środkowoeuropejską. Nie zdołali zbudować federacyjnego państwa równych narodów i ich porażka stała się nieszczęściem dla całej Europy. W 1918 roku niezadowolone narody środkowoeuropejskie rozbiły Cesarstwo, nie zdając sobie sprawy, iż mimo niedostatków było niezastąpione. W ten sposób po I wojnie światowej Europa Środkowa przekształciła się w strefę słabych bezbronnych państewek, umożliwiając pierwsze podboje Hitlerowi i ostateczny triumf Stalinowi. (Kundera 1984) 
Status kanoniczny posiadają trzy główne programowe teksty: Porwanie Zachodu, albo tragedia Europy Środkowej Milana Kundery z roku 1983, opublikowany pod rożnymi tytułami ${ }^{1}$, oraz odczyty Miłosza Nasza Europa i Daniło Kiša Wariacje na tematy środkowo-europejskie, wygłoszone podczas dyskusji na uniwersytecie w Michigan w roku 1986. Wszystkie te trzy teksty są wpisane w konteksty emigracji i dysydenctwa. Znaki wspólnoty i jedności są tu wręcz oczywiste, toczy się między nimi dialog i dyskusja; wpisują się w szerszy, bogatszy i bardziej złożony krąg tekstów i myślicieli z innych krajów słowiańskich i niesłowiańskich, mających tę samą wagę w dyskusji na temat Europy Środkowej. W tej samej ramie czasowej usytuowane są kluczowe poglądy myślicieli z krajów niesłowiańskich, takich jak Emił Cioran (1911-1995), István Bibó (1911-1979), György Konrád (1933-2019) i Jenő Szűcs (1928-1988), natomiast do grona słowiańskich pisarzy należą także inni przedstawiciele tego nurtu, jak Jozef Kroutvor, Drago Jančar, Pavel Vilikovský, a w nowszych czasach - Andrzej Stasiuk, Jurij Andruchowycz. Paleta znanych pisarzy, którzy zabrali głos w tej sprawie jest naprawdę zaskakująco barwna, jest swego rodzaju fenomenem i trwałym powodem do badań środkowoeuropejskiego dyskursu literackiego².

Warto zwrócić uwagę na znaczenie kwartalnika Zeszyty Literackie (tam został opublikowany esej Kundery w 1984 roku), wydawanego od roku 1982 w Paryżu, gdzie sprawom Europy Środka poświęcono specjalne kolumny. Czasopismo to stało się zbornym punktem pisarzy Europy Środka i kwestionowało jej rozumienie. Opublikowano tam teksty autorów, pochodzących z różnych środkowoeuropejskich krajów jak: Rumunia (Emil Cioran, Mircea Eliade), Czech (Václav Havel, Milan Kundera, Vladimír Holan), Serbia (Danilo Kiš), Litwa (Tomas Venclova) oraz oczywiście Polska, gdzie Miłosz, Kołakowski, Michnik stanowią czołówkę. Na lamach Zeszytów Literackich w 1984 roku (rok po jego francuskim wydaniu i w tym samym roku, kiedy ukazało się jego amerykańskie wydanie) opublikowano programowy esej Kundery oraz polemikę tegoż autora z Josipem Brodzkim, z którym polemizował także i jego przyjaciel Miłosz. Wielu z nich nazywano centaurami, posługując się poetycką metaforą Brodskiego.

1 Jak zauważa Ani Burowa, esej Kundery pojawia się pod różnymi tytułami w zależności od odbiorcy, do którego się zwraca. W amerykańskiej prasie ma tytuł The Tragedy of Central Europe (New York Review of Books), jego francuska publikacja ma tytuł L'Occident kidnappé ou la tragédie de l'Europe centrale (Le Debat, 1983), czeska - Únos západu aneb Tragédie střední Evropy (Promeny, 1986 - Burova 2005: 99).

2 Zoran Konstantinović i Fridrun Rinner piszą o trzech głównych liniach tradycji w środkowoeuropejskim dyskursie literackim - dziwność i groteska, mimikria, gra językowa (zob. Drei Traditionssränge des mitteleuropäischen Diskurses, w: Z. Konstantinović, F. Rinner. Eine Literaturgeschichte Mitteleuropas. Innsbuck: Studienverlag, 2003, pp. 354-369). 
Przedstawione przez wskazanych autorów poglądy prezentują kolejną fazę i kolejny układ koncepcji, o których można powiedzieć, że narodziły się na gruzach poprzednich, oraz z rozpadu struktur imperialnych i kolonialnych, dominujących od końca XVIII stulecia do lat 8o. XX wieku - wpisane w postkolonialny dyskurs, ale mimo to noszące ciężar tych koncepcji, z których rozpadu się zrodziły. Na początku swego pierwszego odczytu w Harwardzie Miłosz mówi: Styszę zarzut, że ktokolwiek mówi o Europie Środkowej, wskrzesza widmo Mitteleuropy, bo tak czy owak obszar ten musi być albo strefa wpływów rosyjskich, albo niemieckich. Na to odpowiem, że jeżeli tak ma być zawsze, pakt Mołotow-Ribbentrop 1939 roku, który dokonat podziału terytoriów, byt zaiste wiekopomny (Milosz 1986: 5).

Nieprzypadkowo manifestowali nową koncepcję myśliciele, pochodzący z małych krajów i narodów, w naszym przypadku z krajów słowiańskich, które przez długi czas podlegały władzy imperiów i przeżyły poczucie zagrożenia swojej tożsamości. Z drugiej strony w planie historycznym Czesi, Polacy, Węgrzy, Chorwaci czy Serbowie brali udział w ponadnarodowych strukturach państwowych, gdzie nie zawsze byli w pozycji zawładniętych. Państwo czeskie było głównym tworzywem wskrzeszonego Imperium rzymskiego w złotym wieku XIV za Karola IV i utraciło swoją niezależność w pierwszej połowie XVII w. Retrospekcje Miłosza dotyczą mocnego unijnego związku Rzeczpospolitej obojga narodów (z udziałem ziem białoruskich i ukraińskich). Kroacja zawarła unię dynastyczną z Węgrami na początku XII stulecia i z Habsburgami w wieku XV. Idea obrony tożsamości jest owocem przede wszystkim tych okresów, kiedy były ofiarą obcej władzy, ale musimy myśleć także o tym, że pamięć historyczna jako oś tożsamości zawsze zwraca się do czasów dawnych. Odrodzeniowe idee zjednoczenia Słowian są oczywistym sprzeciwem wobec politycznej zależności.

Kundera określa Europę Środkową jako ojczyznę małych narodów, które nie mają ambicji by zawładnąć innymi narodami. Jako mały naród określa taki naród, który przeżył poczucie zagrożenia ${ }^{1}$. Miłosz poczucie to stawia u podstaw historycznej wrażliwości narodów środkowoeuropejskich i dodaje, że jest ono także przyczyną federalistycznych tendencji oraz zaciekłych nacjonalizmów (Milosz 1986: 5). Danilo Kiš z kolei mówi o małych narodach i językach, ale bardziej zwraca uwagę na relacje między ich losem historyczno-kulturowym i kulturą wiedeńską oraz na rozpad Wiedeńskiego kręgu i jego przyczyny. Kontynuując ideę Kundery o porwaniu narodów środkowoeuropejskich z ich naturalnej strefy Zachodu, pisze, że nowa sytuacja geopolityczna oderwała Wiedeń od jego naturalnych sojuszników, a Budapeszt, Praga, Warszawa i Bukareszt sq dziś bliżej niż dalej Moskwy

1 Ale co to znaczy - mały naród? Proponuję następującq definicję: mały naród to taki, którego istnienie może zostać w każdej chwili zakwestionowane, który może zniknąć i o tym wie (Kundera 1984). 
(Kis 1989: 22). Narody te, do których należą omawiani pisarze, kiedy osiągnęły niezależność narodową i przeżyły koszmar II wojny światowej, narody te, do których należą omawiani pisarzy, wpadły pod nową zależność. Rozpad imperium Habsburgów i klęska idei Wielkich Niemiec są finałem wcześniejszej serii zdarzeń i idei z nimi związanymi. I tu koło się zatacza. Rozpoczyna się nowa seria, nowa zależność, trafiająca w sedno kulturowej egzystencji.

Nieprzypadkowo w dyskusji, trwającej w latach 6o.-8o. drugiej połowy XX wieku dominuje widmowy i nieokreślony charakter Europy Środkowej, co utwierdziło trwały element jej wizytówki. Charakter ten mogli uchwycić i wyrazić najlepiej właśnie pisarze - walczący o swoją tożsamość, nie tylko twórczą, w nieustannej bitwie z historią, określić to, co wymyka się z geopolitycznych map i jest relatywne, według słów Miłosza nie jest pojęciem geograficznym (Milosz 1986: 4). Twórca akcentuje to w odczycie O naszej Europie z 1986 roku, powtarzając oraz parafrazując myśli Kundery z 1983 roku, że dla Węgrów, Czechów i Polaków słowo „Europa” nie oznacza zjawiska ze sfery geografii, lecz jest pojęciem duchowym i na pytanie czy można jq określić geograficznie? Jakie sq jej granice? Kundera odpowiada, że daremnie byśmy próbowali wyznaczyć je ściśle, gdyż Europa Środkowa nie jest państwem, lecz kultura, losem. Jej granice sq wyobrażeniowe i trzeba wyznaczyć je na nowo, wychodząc od każdej nowej sytuacji historycznej. (...) Tym co określa i wyznacza środkowoeuropejskq całość - kontynuuje Kundera - nie mogq więc być granice (nieautentyczne, narzucone przez inwazje, podboje i okupacje), lecz wspólne zasadnicze sytuacje, coraz to inaczej grupujące te narody w wyobrażeniowych $i$ zmiennych granicach, wewnątrz których trwa ta sama pamięć, to samo doświadczenie, ta sama wspólna tradycja (Kundera 1984).

Miłosz kontynuuje i rozwija myśl Kundery pisząc, że uczucia i myśli jej mieszkańców muszą wystarczyć do określenia linii mentalnych które zdają się być trwalsze nic granice państw na mapach świata (Milosz 1986: 4). Danilo Kiš zaś stara się dopowiedzieć, że jest ona bez jasnych granic, bez środka, albo z wieloma środkami i że ryzykownie jest mówić o wspólnym geopolitycznym albo kulturowym fenomenie, że nie można mówić też o niej na poziomie ponadnarodowym (Kis 1989: 22). Kiš, podobnie jak Miłosz, odsyła do myśli Kundery, że Europa Środkowa jest geograficznie położona w centrum, politycznie na wschód, a kulturowo - na Zachód; Budapeszt, Praga, Warszawa i Bukareszt zaś są bliżej do Moskwy niż do Wiednia, z którym były niegdyś naturalnie powiązane. Określa on Europę Środkową jako enklawę o wirtualnym charakterze.

Dyskusje, dotyczące ciała Europy Środkowej bułgarska badaczka Ludmiła Mindova w swoim szkicu Europa Środkowa. Anatomia nostalgii słusznie opiera na eseju Kiša i kojarzy ze znanym obrazem Rembrandta Lekcja z anatomii: 
Moja środkowoeuropejska lekcja z anatomii nie powstała pod dyktando tego eseju Danila Kiša, ale naprawdę właśnie jemu dużo zawdzięcza. Jemu i jednemu obrazowi Rembrandta, a także wielu innym twórcom, którzy zbudowali moje wyobrażenie o tej geograficznej i kulturowej przestrzeni w taki sposób, że mnie wzrusza bardziej jego poetyka, niż geopolityka, poryw geniusza, niż złoczyńcy, stworzenie niż zburzenie. (Mindova 2016: 99)

Jeżeli jako środek Europy zdefiniuje się narody w sytuacji podwładnej, które nie są zaborcami, ale za to są kulturowo i moralnie mocne, to logiczne jest, że istota Europy Środkowej zasadza się na ramach niniejszej interpretacji w identyfikacji z kulturą, jako formą zachowania tożsamości. Wielki wpływ na tę walkę z tożsamościową przestrzenią pustki wywiera własne pochodzenie. Perspektywa słowiańska przejawia się jako antidotum kolonializmu i imperializmu. Imperialna linia Rosji jest traktowana tu jako problem Europy z nią samą (Kundera) ${ }^{1}$, a historia własnego kraju jest źródłem jej doświadczania.

\section{SUWENIRY BIOGRAFII - ŚRODKOWOEUROPEJSKA AUTOREPREZENTACJA} Prezenty biografii to element stały. Pochodzenie, miejsce urodzenia, lata młodości i dalsze koleje życia - to lekcja tożsamości historycznej i kulturowej, której owoce wcielają się w twórczość i przemieniają w uniwersalne przesłania, odziane w szaty artyzmu. Każdy z omawianych tu twórców przeżył los przesiedleńcy, został boleśnie wtajemniczony w misterium płynności historii. Dla każdego z nich sytuacja aktualna stała się sprzeczna z tym, co czuł jako własne dziedzictwo kulturowe i narodowe, zupełnie jakby powtarzała się scena zlepiana z okruchów tożsamości, jakże umiejętnie pokazana tu przez innego węgierskiego pisarza, również przesiedleńca i emigranta, Sándora Máraia (1900-1989) w jego Wyznaniach patrycjusza (Egy polgar vallomasai, 1934), opisanych w tym kontekście przez Andrzeja Nowosada (Nowosad 2006: 147-156).

Litewsko-polskie i wielokulturowe rodzinne pogranicze Miłosza jest idealnym punktem wyjścia do kilku kluczowych punktów widzenia w obecnej interpretacji: 1) konstruowania pamięci historycznej o Rzeczypospolitej Obojga Narodów jako podstawie własnej tożsamości; 2) krytyczno-analitycznego myślenia historycznego i społecznego;3) otwartego i wielokulturowego podejścia do świata; 4) osobistej motywacji i zbiorowego podejścia do problematyki Europy Środkowo-Wschodniej jako miejsca styku wielu kultur i struktur politycznych. Element judaistyczny jest tu kluczowy dla interpretacji Europy Środkowej i pełni niemałą rolę w jego poglądach.

1 Jej prawdziwa tragediq nie jest zatem Rosja, lecz Europa. Ta Europa, która dla szefa węgierskiej agencji prasowej reprezentowała wartość, dla której gotów był zginać i zginąt. Oddzielony żelazną kurtynq nie podejrzewat, że czasy się zmienity i że w Europie Europa przestała być odczuwana jako wartość (Kundera 1984). 
Danilo Kiš to z kolei pisarz pochodzenia serbsko-węgierskiego i żydowskiego ${ }^{1}$, dotknięty koszmarem Holocaustu. Los jego ojca, ofiary faszystowskiego obozu pracy, zostawił swój głęboki ślad w świadomości i wrażliwości pisarza, co widać w takich utworach jak Klepsydra i Encyklopedia umartych.

Rodzinne drzewo historycznych losów i przesiedleńczy los Kiša² oczywiście wywierają wpływ na jego poglądy, nacechowane bogatą erudycją oraz dużą wrażliwością na tematy żydowskie. Pojawia się w nich zmitologizowany obraz Morza Panońskiego (w Klepsydrze), gdzie historyczne morze istniejące $\mathrm{w}$ miocenie i w pliocenie na obszarze dzisiejszej Kotliny Panońskiej (rozciągającej się od dzisiejszych terytoriów Austrii do Kirgistanu odnogi oceanu Tetydy), jako praobraz Europy Środkowej, w którym można odnaleźć ślad dawnej historii Słowian Południowych oraz mit zaginionej Atlantydy. Kiš jest wyjątkowo otwarty na nurty kultury austriacko-węgierskiej. W swoich Wariacjach na tematy środkowoeuropejskie (1986) prowadzi dialog z niemieckim teologiem i filozofem Bruno Bauerem (1809-1882), austriackim literatem Robertem Musilem (1880-1942), austriackim dziennikarzem i pisarzem żydowskiego pochodzenia Josephem Rothem (1894-1939), czy wreszcie z chorwackim pisarzem, ojcem chorwackiej literatury Mirosławem Krležą (1893-1981). Wskazuje w tych dialogach na efemeryczność Europy Środkowej i jej niedookreślonego Centrum, oraz pragnienie udowodnienia wspólnego europejskiego rodowodu. W swojej twórczości Kiš odsyła do wielu biografii ludzi kultury pogranicza o mieszanej krwi, takich jak: węgierski poeta Sándor Petőfi (1823-1849), którego określa mianem zmadziaryzowany Słowianin, czy węgiersko-brytyjski pisarz i dziennikarz Artúr Kösztler (1905-1983), którego węgiersko-czesko-żydowskie pochodzenie jest jak znak zodiakalny, który wyjaśnia wszystkie jego poszukiwania swojego miejsca na ziemi (Kiš 1989: 28). Ważne miejsce w wymienionych przez niego biografiach zajmuje pochodzenie żydowskie opisywanych tu postaci, a takowe mieli przecież i austriaccy pisarze: noblista z 2019 roku Peter Handke (Słowieniec urodzony w Griffen w Karyntii), Joseph Roth (urodzony w Brodach koło Lwowa), Franz Kafka (urodzony w Pradze), czy Zygmunt Freud (urodzony w Příborze). Terror klasycznego antysemityzmu oraz jego kontynuacje - faszyzm i stalinizm - są według Kiša jedną z najgłębszych traum środkowoeuropejskiego intelektualisty, i to właśnie one wyjaśniają dlaczego dziś pisanie i mówienie o Żydach powoduje wyrzuty sumienia i poczucie dyskomfortu (Kis 1989: 28).

Milan Kundera nie ma takiego pogranicznego pochodzenia, jakie mają Kiš i Miłosz. Natomiast jego biografia jest związana z rolą Pragi i jej miejscem w sercu Europy, na skrzyżowaniu kultur. Nieprzypadkowo przypomina czasy Karoła IV, kiedy to Praga była

1 Ojciec Kiša był węgierskim Żydem, a matka pochodziła z Czarnogóry.

2 Do 1948 roku rodzina mieszkała na Węgrzech, następnie wraz z matką przenieśli się do Jugosławii. 
sercem Europy. Jego tożsamość nosi wielowiekową tradycję kulturową Czechów, związaną z Zachodem. Kulturowym i politycznym dramatem jest z kolei porwanie Zachodu ze strony Sowieckiego Wschodu, które dramatycznie wpłynęło na losy środkowoeuropejskich Czechów. Odsyła on do mentalnych światów Franza Kafki i Jaroslava Haška (1883-1923), odkrywając w ich twórczości esencję środkowoeuropejskości - ironię i anonimowość. Z Europą Środkową łączy się jego specyficzna koncepcja śmiechu, który przejawia się po raz pierwszy w Księdze śmiechu i zapomnienia i przenika całą jego twórczość. Odsyłają do Kafki i Haška także Miłosz i Kiš, a ten ostatni uważa nawet, że zagadkowo-symboliczny i anonimowy świat Kafki może byś widziany jako emblemat Środkowoeuropejczyka (Kis 1989: 29).

Dla każdego z tych trzech pisarzy Europa Środkowa / Środkowo-Wschodnia jest elementem autoreprezentacji, legitymizacji twórczej i paszportu do emigracji, życiowej i wewnętrznej. Kiedy chcą opowiadać o sobie mówią o niej i odwrotnie - kiedy chcą ją przedstawić, mówią o sobie. Autobiografizm jest tu niezmienną częścią ich dyskursu środkowoeuropejskiego. Każdy z nich walczy z jej nienamacalnością, peryferyjnością czy problematycznością, z jakąś formą bytu-niebytu w manihejskim podziale (określenie Kiša) Europy na Wschód i Zachód, z wyrwanym Sercem środka - traktowanym jako pozbawienie Europy Środkowej swego centrum. Środkowoeuropejskość najlepiej widać w specyfice literatury i kultury, w eksplozji twórczej XX wieku, - jako tęsknotę za Europą, świadectwem rodowodu - przez długi czas odmawianym przez Historię.

W pierwszym harwardzkim odczycie Zaczynając od mojej Europy Miłosz przedstawia się w taki sposób: Urodziłem się na samej granicy Rzymu i Bizancjum. Czyż to jest możliwie - styszę pytanie - wspominać o tak dawnych, symbolicznych już tylko potęgach? A jednak podział ten przetrwał wieki zakreślając, choć nie zawsze na mapie, pomiędzy domeną katolicyzmu i domena prawosławia. W ciągu wieków Europa utrzymywała ten dawny podział i była poddana prawu osi północ-południe (Milosz 2004: 10). Wkrótce po otrzymaniu Nobla twórca ten opisał w Ameryce terytorium Europy, z której pochodzi jako białą plamę na mapie kultury, jako pustkę, która jest owocem podziału Europy na Wschód-Zachód.

\section{MIŁOSZOWA EUROPA ŚRODKOWO-WSCHODNIA I DAWNA RZECZPOSPOLITA}

Niejednokrotnie Miłosz mówi o znaczeniu konkretnego terytorium ojczystego dla punktu widzenia wobec innych. Na przykład w Rodzinnej Europie podkreślił, że punkt, w którym urodziliśmy się, separuje nas od poglądów, gdzieś indziej przyjętych (Milosz 2001: 19). W harwardzkim wykładzie Zaczynając od mojej Europy zauważył, że wiek XX, bardziej może być proteuszowy i wieloksztattny niż ktokolwiek inny, zmienia się w zależności od punktu, także geograficznego, z którego patrzymy (Milosz 1987: 9). O swoim pochodzeniu wyraża się jako o kontekście, decydującym dla swojej tożsamości i poglądów. Mapa Dawnej 
Rzeczypospolitej stoi u podstaw podejścia geokulturowego i historycznego Miłosza. Jedną z pierwszych oraz podstawowych swoich legitymizacji twórczych Miłosz tworzy w Rodzinnej Europie. Najlepiej wyjaśnia swój pomysł w późniejszym wstępie Przypis po latach, gdzie określa swoją książkę następującymi słowami: Była zarówno kazaniem misjonarza wśród dzikich jak próbq odpowiedzenia na pytanie, kim jestem. Gdybym pochodził z Warszawy czy Krakowa, byto by mi trochę łatwiej to wyjaśnić. (...) Ja jednak chciatem wprowadzić na mapę literatury cały nasz wschodni galimatias, nawet dla większości polskich czytelników obcy (Milosz 2001: 9). Miłosz walczy z poniżonym statutem Europy Wschodniej, ze statusem wschodnich części byłego Państwa Polsko-Litewskiego jako gorszych części Kontynentu - biednego kuzyna. Robi to opowiadając o etapach historii dwu-państwa (i jego destrukcji i transformacji w czasie) na podstawie własnej biografii, jak się można wyrazić autobiografując historię, to znaczy nadając jej interpretację autobiograficzną. Lecz jego autobiografizm wiąże się z rzetelnym dystansem do swojej osoby, gdy pisze: Od razu na wstępie książki deklaruję, że szukam dystansu do swojej osoby i posługuję się nią przykładowo, jako obiektem historycznym czy pokoleniowym (Milosz 2001: 10). W innym miejscu zaś pisze, że traktuje siebie jako obiekt społeczny (Milosz 2001: 16), zaprasza na wyprawę w głąb własnej, jednak nie tylko własnej, przeszłości (Milosz 2001: 13). Biografia Miłosza, powtarzająca typologie literackie Mickiewicza, rozwija i transponuje tożsamościową fabułę romantycznego proroka w nowych czasach. Mickiewicza i Miłosza łączy wspólny stosunek do historii Litwy, jako historii własnej. Ich obrazy dawnej Rzeczypospolitej dzieli dystans półtora wieku.

Miłosz nie idealizuje przeszłości Pierwszej Rzeczypospolitej, a przede wszystkim bada ją i analizuje, chociaż odnosi się do niej nostalgicznie, jak do swojej prawdziwej historyczno-kulturowej ojczyzny, pisząc z pozycji świadka i spadkobiercy. Jego sposób opowiadania historii robi wrażenie - ukazuje ją obustronne, wyjaśniając różne punkty widzenia

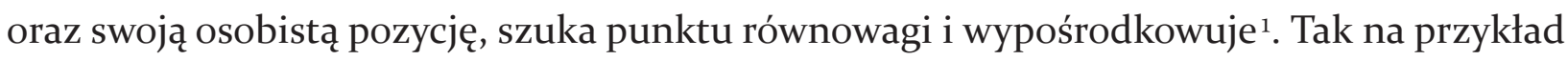
pisząc o historii Unii Polsko-Litewskiej, przedstawia on spory jej dotyczące, których był świadkiem w młodości i dzieciństwie - czy stanowi pokojowy pochód cywilizacji przeciw okrutnym metodom Teutonów albo organizm państwowy rozwijający się pod polska dominacją, wiodącą do zamierania języka litewskiego (Milosz 2001: 20-21). Równowagę tę stara się zachować w trakcie opowiadania i interpretacji nie tylko w Rodzinnej Europie. To, do czego zawsze odnosi się krytycznie, jest nacjonalizm, z jednej i z drugiej strony byłych części Dawnej Rzeczpospolitej.

1 Równowagę osiąga w ramach lokalnej ojczyzny, miejsca urodzenia, do którego w sposób naturalny człowiek zostaje przywiązany przez całe życie i do niego wraca nostalgicznie. 
Jeżeli spojrzeć na opis i opowiadanie historyczne Miłosza o dwu-państwie (Commonwealth of Nations) w Rodzinnej Europie, zobaczymy szereg wymienionych cech, dotyczących istoty omawianej XX-wiecznej koncepcji Europy Środkowej - głównie w rozdziałach Miejsce urodzenia, Przodkowie, Dalszy ciąg wojen i Narodowości, ale przenikających przecież całą książkę. Wśród nich są: ponadnarodowy, wieloetniczny i wielowyznaniowy charakter państwa (szczególną uwagę zwrócono na historię Żydów, ważną dla historii Commonwealth i dla istoty Europy Środkowej); rola inwazji wschodniej (rosyjskiej i sowieckiej) i faszystowskiej; przemiany, związane z wojnami XX wieku. Przedstawia on różnorodność narodową, etniczną i religijną, stawiając akcent na wydarzeniach i procesach, których był świadkiem, nie zapominając o przeszłości, której stał się spadkobiercą.

Oczywiście ważne miejsce zajmuje tu relacja polsko-litewska - w czasach istnienia Dawnej Rzeczypospolitej i po jej rozbiorach. Miłosz wskazuje bardziej na hierarchiczność niż na polarność relacji: wysoka, pańska polska kultura - chłopska i prowincjalna litewska; utożsamienie polskości z rzymskim katolicyzmem - lokalna rola litewskiej pogańskości; dominujący z czasem język polski jako język kultury i panującej klasy - litewski i dialekty, później zaklasyfikowane jako języki ukraiński i białoruski, które schodziły do rzędu mowy gminu (Milosz 2001: 22). Po przedstawieniu tego hierarchicznego modelu Miłosz konkluduje, że z językiem jednak nie łączono idei narodu. Lojalności były oparte na poczuciu związania z terytorium (Milosz 2001: 22). Ze względu na wyznania, oprócz łączącej człowieka z przyrodą pogańskości, ważna jest przebiegająca przez środek państwa linia graniczna między katolicyzmem i prawosławiem (Milosz 2001: 22). W Zaczynając od mojej Europy, żeby wyjaśnić swoje wyznanie Miłosz cytuje swój wiersz Rue Decartes i wyjaśnia, że pogańska świętość wodnego węża była dla niego czymś ważniejszym i mocniejszym niż narzucone przez katolicyzm poczucie winy (Milosz 1987: 7).

Ogromnie ważna jest dla Miłosza kulturowa jedność z Europą, widoczna na przykład w barokowym Wilnie. W O naszej Europie mówi Miłosz, że Europę Środkową można poczuć idąc ulicami jej miast, trudno wątpić o jej upartym życiu, czy to będzie w moim barokowym Wilnie, czy w inaczej barokowej Pradze, czy w średniowieczno-renesansowym Dubrowniku (Milosz 1986: 4). O baroku jako znaku kulturowej tożsamości Europy piszą także Kundera i Kiš.

Los Commonwealth określa Miłosz jako drogę do zmiany w równowadze sił Europy. Zasługuje na uwagę wywód, że właśnie rozkład wewnętrzny dwu-państwa, zajmującego cały środek Europy otworzył w XVIII wieku drogę Rosji i zmienit radykalnie równowagę sił (Milosz 2001: 21). Żeby pokazać przełom moskiewskiej inwazji, w swoim wileńskim przemówieniu z 1999 roku Aby duchy umartych zostawity nas w spokoju Miłosz powraca do okresu wojen polsko-szwedzkich: 
Wielkie Księstwo, a następnie polsko-litewska Rzeczypospolita długo opierały się skutecznie Moskwie, aż do przełomu, który, moim zdaniem, nastąpił w roku 1655. Wtedy terytorium Polski najechali Szwedzi, natomiast od wschodu ruszyła armia rosyjska i zajęła Wilno. Rosjanie podpalili miasto i dokonali masowej rzezi jego mieszkańców. Wyparci z Wilna zostali dopiero w $1661 \mathrm{r}$. Wydarzenia te można uznać za początek ekspansji rosyjskiego imperium, którego kolejne działania polityczne w Wilnie dziś określa się mianem rusyfikacji. (Milosz 1999)

W Rodzinnej Europie Miłosz nazywa się dzieckiem klęski i snuje rozważania nad przyczynami upadku Commonwealth, które rozpadło się na narodowości, nienawidzące Rosji, ale również nienawidzące siebie nawzajem (Milosz 2001: 26). Pisarz krytycznie ocenia przyczyny wewnętrzne (kontrasty, samobójczą wolność opinii, różne formy społecznego chaosu) i jednocześnie wyraża nienawiść wobec przebiegłych wrogów z zewnątrz.

Szczególną uwagę Miłosz zwraca na czynione przez Józefa Piłsudskiego (1867-1935) próby odrestaurowania Commonwealth, które określa jako sen anachroniczny albo zbyt nowoczesny (Milosz 2001: 63). Jego zdaniem Marszałek Piłsudski przyjął wizję państwa ponadnarodowego, obejmującego Królestwo i Wielkie Księstwo Litewskie z ostatniej fazy jego istnienia w zbiorowej pamięci, czyli z XVIII wieku. Sanacyjne poglądy polityczne Piłsudskiego Miłosz tłumaczy jego szlacheckim pochodzeniem z rodziny o tradycjach patriotycznych i powstańczych, ale też terytorialnych (Piłsudski urodził się w Zułowie na Wileńszczyźnie) wywodząc, że tylko jego pochodzenie terytorialne wyjaśnia jego decyzje (Milosz 2001: 63). Próba restytucji Commonwealth była motywowana, według niego, nie napaścią na ziemie ruskie, a wyprawą po swą własność, zagarniętą przez carat. Głównego wroga Piłsudskiego Miłosz widzi w polskich nacjonalistach, a Feliksa Dzierżyńskiego, polskiego i radzieckiego działacza komunistycznego, twórcę i szefa pierwszych sowieckich organów bezpieczeństwa postrzega jako jego duchowego kuzyna ze wzłędu na pochodzenie i charakter idei, lecz idącego inną drogą:

Zdaje się, że wiele światła na jego osobę [Piłsudskiego - M. G.] rzuciłaby paralela z jego duchowym kuzynem, Feliksem Dzierżyńskim. Obaj pochodzili z niezamożnych rodzin szlacheckich, urodzili się w niewielkiej odległości jeden od drugiego na Litwie historycznej, obaj zostali zawodowymi rewolucjonistami, akcje bojowe i pobyt w carskich więzieniach urozmaicając lekturą polskich poetów romantycznych. Kto wie, może obaj byli bardziej poetami niż politykami, ale poetami, używającymi krwi zamiast atramentu. (...) Kiedy jeden dążył przede wszystkim do wyzwolenia się od Rosji - carskiej i niecarskiej - drugi stawiał na rewolucję w skali całego globu i jako prawa ręka Lenina posiadł nieograniczoną władzę nad ciałami i duszami mieszkańców olbrzymiego państwa. (Milosz 2001: 62-63)

Kompromisowy traktat ryski z 1921 roku jest - zdaniem Miłosza - dalszym przecinaniem dawnego Wielkiego Księstwa. Jego Rodzinna Europa może być więc czytana zatem jako 
książka o podzielonej przez historię mapie Dawnej Rzeczypospolitej Obojga Narodów - mapie etnicznych, wyznaniowych, społecznych, językowych i kulturowych podziałów, również w XX wieku.

Wilno, dzisiejsza stolica Litwy i centrum kulturowe dawnej Rzeczypospolitej Obojga Narodów w niemałym stopniu utożsamia dziś jeszcze kreśloną piórkiem historii Miłoszową mapę. Miłosz, pisząc o Wilnie, w Rodzinnej Europie przedstawia go w kontekście historii - dawnej i tej, której był świadkiem; gdy publikuje Dialog o Wilnie w paryskiej Kulturze (z Tomasem Venclovą), uwypukla jego dwoistość (Miłosz 1979: 3-37); gdy wraca do Wilna pod koniec XX wieku, czuje się w nim tak, jakby obarczony bagażem etnicznych tożsamości chodził po cieniutkim lodzie historii: Niestety, przyjeżdżając do Wilna zawsze mam wrażenie, że trzeba tu chodzić jak po cienkim lodzie, i że nie wystarcza tutaj być człowiekiem, bo każdego natychmiast zapytaja, czy jest Litwinem czy Polakiem, Żydem czy Niemcem, jakby ponury wiek dwudziesty, wiek etnicznych podziatów, trwał tu dalej w najlepsze (Milosz 1999).

Z drugiej strony miasto odzwierciedla zarówno wielość w jedności, jak i jedność w wielości. Jedność byłego państwa, wielość narodów, wyznań i kultur, podziały powodowane historią, głównie po XVIII stuleciu: Czy istnieje wiele miast, co do których nazwy brak zgody - pyta w Rodzinnej Europie. - Polacy mówiq Wilno. Litwini: Vilnius, Niemcy: Vilna, Białorusini: Wilnia (Milosz 2001: 67). Dwoistość Wilna najlepiej widać w Dialogu o Wilnie i Rodzinnej Europie (na przykład w opisie relacji między Wilnem żydowskim i Wilnem polskim), wielość i jedność - we wszystkich poddanych tu analizie tekstach. Dialog o Wilnie jest zatem częścią dialogicznych tekstów między Czesławem Miłoszem i wędrownym mędrcem Tomasem Venclovą, choć obaj są poetami, obaj - dysydentami, obaj urodzili się na Litwie. Dwaj poeci, jeden litewski, drugi polski, wychowali się w tym samym mieście. (...), po czym prowadzi do rozdwojonej historii miasta, nazywanego Jerozolima Pótnocy (taka nazwa występuje już w Rodzinnej Europie) i miastem zwartym w sobie (por. Psalm 122:3 $)^{1}$ oraz porównuje do odwiedzonej w młodości Pragi, Krakowa, czy Warszawy, którą (oczywiście z wielu przyczyn) niejednokrotnie przeciwstawia terenom, do których czuł bliskość. Ogłaszając najpierw, że zostaje wierny Litwie (tak jak Stanisław Vincenz Karpatom), w następującej charakterystyce Wilna Miłosz czyni uwagi i uogólnienia, dotyczące przedwojennej prowincjonalności tego miasta. $Z$ jednej strony przeciwstawia się polskiemu nacjonalizmowi, z drugiej wyjaśnia status Wilna jako enklawy w sposób, który przypomina wyżej omawiane charakterystyki Europy Środkowej - enklawy Europy (akcentowane też przez Kiša): Myślę, że dzisiaj młodym bardzo trudno zrozumieć ten charakter

1 Jeruzalem, wzniesione jako miasto o gęstej i zwartej zabudowie (Psalm 122:3). 
przedwojennego Wilna jako enklawy: ni to Polska, ni to nie Polska, ni to Litwa, ni to nie Litwa, ni to prowincja, ni to stolica, choć przede wszystkim prowincja. I oczywiście Wilno, jak widzę z perspektywy, było dziwacznie, miastem pomieszanych, zachodzacych na siebie stref jak Triest albo Czerniowce (Milosz 1999).

Miłosz podkreśla także mechanizmy mitologizacji litewskich miast. Wilno jest dla niego mocno i wieloznacznie zmitologizowanym miastem: Niewiele jest miast $w$ Europie, które by były poddawane takim mitologizacjom jak Wilno. Rozumiem przez to opowieści wzięte z przeszłości i niekoniecznie zgodne z faktami. Historia tego miasta jest tak dziwaczna, że po prostu zaprasza, żeby przenosić ją w wymiar baśni, co też nieraz czyniono, i opowieści zmieniały się zależnie od tego, kto opowiadał: czy byli to Litwini czy Polacy, Żydzi czy Białorusini (Milosz 1999).

Wyżej wymienione aspekty Miłoszowskiego Commonwealth w kontekście dialogu o Europie Środkowej są zaledwie krótkim zarysem niezrównanie szerszego i szczegółowego obrazu Wilna, Litwy i Europy Środkowo-Wschodniej w jego twórczości. Miłosz jest przenikliwym historykiem i kronikarzem. Opowiada on o państwach i miastach w narracji przeżytych osobistych historii - osobistego losu. A swój los uważa za jeden z wielu: Ten melanż krwi polskiej, litewskiej i niemieckiej, jakiego jestem przykładem, był czymś powszechnym i niewiele pola do popisu mogli by tu znaleźć zwolennicy czystości. A caty ten zespół pojęć kulturalnych łączył się z Commonwealthem, a przez niego z Polska (Milosz 2001:34).

Na zakończenie nie można pominąć istniejącego w zmniejszonej perspektywie regionalnego modelu, który bardziej koncentruje się na środku Europy, oddala się od Wschodu i jego dylematów oraz od zasady słowiańskości - a mianowicie modelu Grupy Wyszehradzkiej. W przededniu zbliżającej się 30 rocznicy powstania Czwórki jest on jedną z wysp w przestrzeni poruszonej mapy, o której pisał Przemysław Czapliński. 


\section{REFERENCES}

(All online sources last accessed: 10.09.2020)

Ash 1990: Ash, Timothy Garton. “Does Central Europe Exist?” In Ash, T. G. Pomimo i wbrew. Eseje o Europie Srodkowej. Transl. by Anna Husarska, Jarosław Anders: 168-175. London: Polonia, 1990. [In Polish: Ash, Timothy Garton. „Czy Europa Środkowa istnieje?”. W: Ash, Timothy Garton. Pomimo i wbrew. Eseje o Europie Środkowej. Przeł. Anna Husarska, Jarosław Anders: 168-175. Londyn: Polonia, 1990.]

Ash 2017: Ash, Timothy Garton. „Is Europe Disintegrating?” Cental European Review, published 13.06.2017. http://przegladse.pl/?p=5481. [In Polish: Ash, Timothy Garton. „Czy Europa się rozpada?" Przegląd Środkowoeuropejski, 13.06.2017.]

Bachnewa 2013: Bachnewa, Kalina. "New Bulgarian Translations of Czesław Miłosz's Works." Postscriptum Polonistyczne, no 2, (2013): 166-175. [In Polish: Bachnewa, Kalina [Бахнева, Калина]. „Najnowsze bułgarskie przekłady Czesława Miłosza.” Postscriptum Polonistyczne, no 2 (2013): 166-175.]

Bobrownicka 1995: Bobrownicka, Maria. Narcotic Power of Myths. Studies on National and Cutural Awareness of the West and South Slavs. Krakow: Universitas, 1995. [In Polish: Bobrownicka, Maria. Narkotyk mitu. Szkice o świadomości narodowej i kulturowej Stowian zachodnich i południowych. Kraków: Universitas, 1995.]

Burova 2005: Burova, Ani. “The Script of Utopia.” Ezik i Literatura, no 1-2 (2005): 99-104. [In Bulgarian: Бурова, Ани. „Почеркът на утопията.“ Език и литература, по 1-2 (2005): 99-104.]

Burova 2015: Burova, Ani. The Literature and the Fragmented World. Sofia: Paradigma, 2015. [In Bulgarian: Бурова, Ани. Литературата и фрагментаризираният свят. София: Парадигма, 2015.]

Cobel-Tokarska 2013: Cobel-Tokarska, Marta. "Central Europe, Old and New Meanings.” In Firkowska-Mankiewicz, Anna \& Tatiana Kanasz \& Elzbieta Tarkowska eds. Short Lectures on Sociology. Categories, Problems, Sub-disciplines: 172-192. Warszawa: Wydawnictwa Akademii Pedagogiki Specjalnej im. Marii Grzegorzewskiej. https://depot.ceon.pl/handle/123456789/6221. [In Polish: Cobel-Tokarska, Marta. „Europa Środkowa - dawne i nowe znaczenia.”

W: Firkowska-Mankiewicz, Anna \& Tatiana Kanasz \& Elżbieta Tarkowska, red. Krótkie wykłady z socjologii. Kategorie, problemy, subdyscypliny: 172-192. Warszawa: Wydawnictwa Akademii Pedagogiki Specjalnej im. Marii Grzegorzewskiej, 2013.]

Czarnocki 1994: Czarnocki, Adam. "Central Europe: East-Central Europe: the Geopolitical and Cultural-Historical Understanding of the Notions." Annales Universitatis Mariae CurieSkłodowska. Sectio K. Politologia, no 1-2 (1994): 23-35. http://dlibra.umcs.lublin.pl/dlibra /plain-content?id=488o\#. [In Polish: Czarnocki, Adam. „Europa Środkowa: Europa ŚrodkowoWschodnia: geopolityczne a historyczno-kulturowe rozumienie pojęć." Annales Universitatis Mariae Curie-Skłodowska. Sekcja K. Politologia, no 1-2 (1994): 23-35.]

Dybkowska \& Zaryn \& Zaryn 2002: Dybkowska, Alicja \& Zaryn, Jan \& Zaryn, Malgorzata. A Synthesis of Polish History from Earliest Times to the Present Day. Warsaw: PWN, 2002. [In Polish: 
Dybkowska, Alicja \& Żaryn, Jan \& Żaryn, Małgorzata. Polskie dzieje od czasów najdawniejszych do wspótczesności. Warszawa: PWN, 2002.]

Grigorov 2005: Grigorov, Dobromir. "Central Europe: The Way We Are?” Ezik i Literatura, no 1-2 (2005): 75-83. [In Bulgarian: Григоров, Добромир. „Средна Европа: Защо сме такива?“ Език и литература, по 1-2 (2005): 75-83.]

Grigorowa 2013: "Miłosz's Long Anniversary Year in Bulgaria and the Native Realm - Translation of the Title of the Novel as a Motif for Literary Analyses." Postscriptum Polonistyczne, no 2 (2013): 177-19o. [In Polish: Grigorowa, Margreta. „Długi Rok Miłosza w Bułgarii i Rodzinna Europa: Przekład tytułu Rodzinnej Europy jako motyw analizy literackiej." Postscriptum Polonistyczne, no 2 (2013): 177-19o.]

Halecki 1943: Halecki, Oskar. "East Central Europe in Postwar Organization”. Annals of the American Academy of Political and Social Science, vol. 228, (1 / 1943): 51-59.

Halecki 1950: Halecki, Oskar. The Limits and Divisions of European History. London - New York: Sheed \& Ward, 1950.

Halecki 1952: Halecki, Oskar. The Borderlands of Western Civilization. A History of East Central Europe. New York: Ronald Press, 1952.

Halecki 1994: Halecki, Oskar. Limits and Divisions of Europe. Lublin: Instytut Europy SrodkowoWschodniej, 1994. [In Polish: Halecki, Oskar. Historia Europy - jej granice i podziały. Lublin: Instytut Europy Środkowo-Wschodniej, 1994.]

Kloczowski 1993: Kloczowski, Jerzy. East Central Europe in the Historiography of Countries of the Region. Lublin: Instytutu Europy Srodkowo-Wschodniej, 1993. [In Polish: Kłoczowski, Jerzy. Europa Środkowo-Wschodnia w historiografii krajów regionu. Lublin: Instytutu Europy ŚrodkowoWschodniej, 1993.]

Kloczowski 1998: Kloczowski, Jerzy. Younger Europe. Central and East Europe in the Circle of Medieval Christian Civilization. Warsaw: PIW, 1998. [In Polish: Kłoczowski, Jerzy. Młodsza Europa. Europa Środkowo-Wschodnia w kręgu cywilizacji chrześcijańskiej średniowiecza. Warszawa: PIW, 1998.]

Kloczowski 2013: Kloczowski, Jerzy. "Central and East Europe as a Subject of Research." Kwartalnik Historyczny, no 4 (2013): 833-843. [In Polish: „Europa Środkowo-Wschodnia jako przedmiot badań." Kwartalnik Historyczny, no 4 (2013): 833-843.]

Kis 1989: Kis, Danilo. "Variations on the Theme of Central Europe." Res Publica, no 1 (1989): 21-29. [In Polish: Kiš, Danilo. “Wariacje na tematy środkowoeuropejskie.” Tłum. Kazimierz Żórawski. Res Publica, no 1 (1989): 21-29.]

Kundera 1984: Kundera, Milan. “The Tragedy of Central Europe.” Zeszyty Literackie, no 5 (1984): 14-31. [In Polish: Kundera, Milan. "Zachód porwany albo tragedia Europy środkowej." Zeszyty Literackie, no 5 (1984): 14-31.]

Milosz \& Venclova 1979: Milosz, Czeslaw \& Tomas Venclova. "A Dialogue about Vilnius." Kultura, no 1-2 (376-377 / 1979):3-37. [In Polish: Miłosz, Czesław \& Tomas Venclova, „Dialog o Wilnie.” Kultura, no 1-2 (376-377 / 1979): 3-37.]

Milosz 1986: Milosz, Czeslaw. "About Our Europe. Between East and West." Kultura, no 4 (436 / 1986): 3-12. [In Polish: Miłosz, Czesław, „O naszej Europie”, Kultura, no 4 (436 / 1986): 3-12.]

Milosz 1999: Milosz, Czeslaw. "So That the Spirits of the Dead Leave Us in Peace." (Speech from 02.10.1999 in Vilnius.) https://www.milosz.pl/przeczytaj/esej/35/ 
aby-duchy-umarlych-zostawily-nas-w-spokoju-szukanie-ojczyzny. [In Polish: Miłosz, Czesław. „Aby duchy umarłych zostawiły nas w spokoju.” (Przemówienie z 02.10.1999 w Wilnie.)]

Milosz 2oo1: Milosz, Czeslaw. Native Realm: A Search for Self-Definition. Krakow: Znak, 2001.

[In Polish: Miłosz, Czesław. Rodzinna Europa. Kraków: Znak, 2001.]

Milosz 2004: Milosz, Czeslaw. The Witness of Poetry. Krakow: Wyd. Literackie, 2004. [In Polish: Miłosz, Czesław. Świadectwo poezji: sześć wykładów o dotkliwościach naszego wieku. Kraków: Wyd. Literackie, 2004.]

Mindova 2016: Mindova, Lyudmila. The Other Ithaca: On the Home of Literature. Sofia: Iztok - Zapad, 2016. [In Bulgarian: Миндова, Людмила. Другата Итака. За дома на литературата. София: Изток - Запад, 2016.]

Nowosad 2006: Nowosad, Andrzej. "The Road to Identity in the Shadow of the Myth of the Empire: Sándor Márai's Confessions of a Patrician." In Wisniewska, Lidia, ed. Literary Paths to the Myth: 147-156. Bydgoszcz: Wyd. Uniwersytetu Kazimierza Wielkiego, 2006. [In Polish: Nowosad, Andrzej. „Droga do tożsamości w cieniu mitu imperium. Wyznania patrycjusza Sándora Máraiego.” W: Wiśniewska, Lidia, red. Literackie drogi wobec mitu: 147-156. Bydgoszcz: Wyd. Uniwersytetu Kazimierza Wielkiego, 2006.]

Podraza 2004: Podraza, Antoni. "Central Europe as a Historical Region." Report at the 17. Gerenal Congress of Polish Historians, 15-18.08.2004. Printed edition: Podraza, A. Europe, Galicia, Regions. Historical Writings: 27-38. Krakow: Ksiegarnia Akademicka, 2006. [In Polish: Podraza, Antoni. „Europa Środkowa jako region historyczny.” Referat: 17. Powszechny Zjazd Historyków Polskich, 15-18.08.2004. Wydanie książkowe: Podraza, A. Europa, Galicja, regiony. Pisma historyczne: 27-38. Kraków: Księgarnia Akademicka, 2006.]

Pospiszil 2011: Pospiszil, Karolina. "We are the Question. Notes to a Discussion of Central European (Non) Identity.” Kultura i Polityka, no 10 (2011): 141-153. [In Polish: Pospiszil, Karolina. „Jesteśmy pytaniem. Przyczynek do dyskusji o środkowoeuropejskiej (nie) tożsamości." Kultura i Polityka, no 10 (2011): 141-153.]

Stolarz 2013: Stolarz, Agata. "Unbearable Burden of History? Central European Discourse from the 8o's until the Present Day." Rocznik Instytutu Europy Srodkowo-Wschodniej, no 1 (2013): 23-39. [In Polish: „Nieznośny ciężar historii? Dyskurs środkowoeuropejski od lat osiemdziesiątych do współczesności." Rocznik Instytutu Europy Środkowo-Wschodniej, no 1 (2013): 23-39.]

Todorova 2009: Todorova, Maria. Imagining the Balkans. Oxford University Press, 2009. 